\title{
PEMANFAATAN LOKALISASI PROSTITUSI UNTUK PENDAPATAN ASLI DAERAH (PAD)
}

\author{
Krista Surbakti 1) Permai Yudi 2) \\ ${ }^{122)}$ Universitas Quality \\ Email: krista.surbakti8484@gmail.com
}

\begin{abstract}
ABSTRAK
Penelitian ini bertujuan untuk menjelaskan manfaat lokalisasi prostitusi jika dikelola dengan baik oleh pemerintah daerah sebagai bagian dari sumber pendapatan daerah tetapi sesuai dengan ketentuan moral dan etika masyarakat. Latar belakang penelitian ini adalah karena pemerintah tidak mampu mengatasi masalah pelacuran di daerah dan masalah ini sudah lama tidak dapat diselesaikan dan menjadi masalah kontroversial didalam masyarakat, maka dariitu pemerintah dapat mengambil sikap positif dan kooperatif dengan memanfaatkannya sebagai sumber pendapatan daerah. Penelitian ini dilakukan di Desa Bandar Baru Kabupaten Deli Serdang, di mana prostitusi sering terjadi di lingkungan ini tetapi bukan merupakan lokalisasi, dalam arti bahwa kegiatan prostitusi di desa ini adalah ilegal dan tidak berkontribusi signifikan terhadap kas daerah. Teknik pengumpulan data yang digunakan adalah Observasi di mana pengamatan adalah cara melihat atau mengamati suatu peristiwa dari luar ke dalam dan kemudian menggambarkannya persis seperti apa yang dilihat dan diamati. Pengamatan tidak terbatas pada penglihatan (visual), tetapi pengalaman yang didapat dari pendengaran. Observasi yang dilakukan adalah partisipant observer. Pengamatan partisipasi dengan teknik "pengamatan partisipan paruh waktu" dipilih sehingga peneliti dapat langsung terlibat di lapangan tanpa harus tinggal di lapangan. Dengan demikian data dapat diperoleh secara objektif dan terencana.
\end{abstract}

\begin{abstract}
This research aims to explain the benefits of prostitution localization if it is managed well by the regional government as part of the source of local revenue but in terms of the moral and ethical aspects of the community. The background of this research is because the government is unable to overcome prostitution problems in the region and this problem has long been unable to be resolved and becomes a controversial issue within the community, then the government can take positive and cooperative attitudes by utilizing it as a source of local revenue. This research was conducted in Bandar Baru Village. Deli Serdang Regency where prostitution often occurs in this environment but is not a localization of prostitution, in the sense that prostitution activities in the village are illegal and do not contribute significantly to the local treasury. The data collection technique used is Observation where observation is a way of seeing or observing an event from the outside to the inside and then describing it exactly as what is seen and observed. Observation is not limited to vision (visual), but the experience gained from hearing. The observation made was participation observation. Observation of participation with the technique "part time participant observer" was chosen so that researchers can be directly involved in the field without having to stay in the field. Thus the data can be obtained objectively and planned.
\end{abstract}

Keywords: Prostitution, Local Revenue, Government 


\section{PENDAhuluaN}

\section{I.1. Latar Belakang Masalah}

Masalah prostitusi merupakan masalah sosial karena perbuatan tersebut menyimpang dari norma-norma dan nilai-nilai masyarakat. Banyak istilah yang digunakan untuk menyebut pelaku prostitusi ini seperti WTS, PSK, pelacur, balon, sundel dan kupu-kupu malam. Prostitusi telah ada sejak zaman dahulu kala hingga sekarang, namun belum ada yang mengetahui secara pasti kapan munculnya prostitusi. Konon masalah prostitusi lahir bersamaan dengan lahirnya norma perkawinan. Adapun kegiatan prostitusi adalah melakukan hubungan seksual dengan laki-laki diluar perkawinan dan berganti-ganti pasangan, serta untuk melakukannya menerima uang atau bentuk material yang lain.

Adapun pengertian WTS menurut Soedjono D. (1977) adalah sebagai berikut :

"Wanita Tuna Susila atau wanita pelacur adalah wanita yang menjual tubuhnya untuk memuaskan seksual laki-laki siapapun yang menginginkannya, dimana wanita tersebut menerima sejumlah uang atau barang (umumnya dengan uang dari laki-laki pemakainya)

Dalam kehidupan sekarang ini keberadaan Wanita Tuna Susila atau sering disebut PSK merupakan fenomena yang tidak asing lagi dalam kehidupan masyarakat Indonesia akan tetapi keberadaan tersebut ternyata masih menimbulkan pro dan kontra dalam masyarakat. Pertanyaan, apakah kaum pekerja seks termasuk kaum yang tersingkirkan atau kaum yang terhina? Hal tersebut mungkin sampai sekarang belum ada jawaban yang dirasa dapat mengakomodasi konsep pekerja seks komersial itu sendiri. Hal ini sebagian besar disebabkan karena mereka tidak dapat menanggung biaya hidup.

$$
\text { Prostitusi disini bukanlah }
$$

semata-mata merupakan gejala pelanggaran moral tetapi merupakan suatu kegiatan perdagangan. Kegiatan prostitusi ini berlangsung cukup lama, hal ini mungkin disebabkan karena dalam prakteknya kegiatan tersebut berlangsung karena banyaknya permintaan dari konsumen terhadap jasa pelayanan kegiatan seksual tersebut. Oleh sebab itu semakin banyak pula tingkat penawaran yang ditawarkan.

Jika dilihat dari pandangan yang luas, kita akan mengetahui bahwa sesungguhnya yang dilakukan pekerja seks komersial adalah suatu jaringan perdagangan yang melibatkan banyak pihak. Jaringan perdagangan ini juga membentang dalam wilayah yang lebih luas, yang kadang-kadang tidak hanya didalam suatu negara tetapi beberapa negara.

Oleh sebab itu perlu diakui bahwa eksploitasi seksual, pelacuran dan perdagangan manusia semuanya adalah tindakan kekerasan terhadap perempuan dan karenanya merupakan pelanggaran martabat perempuan dan juga merupakan pelanggaran berat hak azasi manusia. Jumlah perempuan pekerja seks meningkat secara dramatis diseluruh dunia karena sejumlah alasan ekonomis, sosial dan kultural.

Dalam kasus-kasus tertentu perempuan yang terlibat telah mengalami kekerasan patologis atau kejahatan seksual sejak masa anak. Lain-lainnya terjerumus kedalam guna untuk mendapatkan nafkah yang mencukupi bagi diri sendiri atau keluarganya, beberapa mencari sosok ayah atau relasi cinta dengan seorang pria, lainnya lagi karena untuk melunasi hutang. Beberapa meninggalkan keadaan kemiskinan di daerah asalnya, dalam kepercayaan bahwa pekerjaan yang ditawarkan akan mengubah hidup mereka.

\section{I.2. Tujuan Khusus}

1. Mengamati seberapa besar penghasilan WTS dan Germo/Mucikari setiap harinya 
2. Mengamati setoran penghasilan WTS kepada Germo/Mucikari

3. Mengamati kelompok/organisasi yang terlibat dalam kegiatan prostitusi tersebut.

\section{I.3. Urgensi Penelitian}

Penelitian ini akan menghasilkan pengetahuan mengenai besarnya perputaran uang yang terjadi di tempat kegiatan prostitusi dan bila dimanfaatkan oleh pemerintah daerah akan memberikan sumbangsih yang besar untuk kas negara yaitu pendapatan asli daerah yang berguna bagi keuangan daerah dapat diartikan sebagai: "semua hak dan kewajiban yang dapat dinilai dengan uang, demikian pula segala sesuatu baik berupa kekayaan daerah sepanjang belum dimiliki/ dikuasai oleh negara atau daerah yang lebih tinggi serta pihak-pihak lain sesuai ketentuan/ peraturan perundangan yang berlaku", Pulungan, (2014). Sumber keuangan daerah adalah sumber yang dapat dijadikan sarana untuk pembiayaan kegiatan daerah dan masuk pada kas daerah. Dalam Undang-undang No 33 Tahun 2004 pasal 5 disebutkan bahwa Sumber Penerimaan Daerah adalah sebagai berikut:

1. Penerimaan Daerah dalam pelaksanaan Desentralisasi terdiri atas Pendapatan Asli Daerah dan Pembiayaan.

2. Pendapatan Daerah sebagaimana dimaksud pada ayat (1) bersumber dari:
a. Pendapatan Asli Daerah
b. Dana Perimbangan
c. Pendapatan Lain-lain

3. Pembiayaan sebagimana dimaksud pada ayat (1) bersumber dari:

a. Sisa lebih perhitungan anggaran daerah

b. Penerimaan Pinjaman Daerah

c. Dana Cadangan Daerah

Pendapatan Asli Daerah (PAD) adalah pendapatan yang diperoleh daerah yang dipungut berdasarkan peraturan daerah sesuai dengan peraturan perundangundangan (Suhadak \& Trilaksono, 2010).

Pendapatan asli daerah bersumber dari:

(a) Pajak daerah

(b) Retribusi daerah

(c) Hasil pengelolaan kekayaan daerah yang dipisahkan

(d) Lain-lain pendapatan asli daerah yang sah.

\section{KAJIAN TEORI}

Menurut Warsito (2010)

Pendapatan Asli Daerah "Pendapatan asli daerah (PAD) adalah pendapatan yang bersumber dan dipungut sendiri oleh pemerintah daerah. Sumber PAD terdiri dari: pajak daerah, restribusi daerah, laba dari badan usaha milik daerah (BUMD), dan pendapatan asli daerah lainnya yang sah". Sedangkan menurut Herlina Rahman(20011) Pendapatan asli daerah Merupakan pendapatan daerah yang bersumber dari hasil pajak daerah ,hasil distribusi hasil pengelolaan kekayaan daerah yang dipisahkan dan lain-lain pendapatan asli daerah yang sah dalam menggali pendanaan dalam pelaksanaan otoda sebagai perwujudan asas desentralisasi.

Dalam upaya memperbesar peran pemerintah daerah dalam pembangunan, pemerintah daerah dituntut untuk lebih mandiri dalam membiayai kegiatan operasionah rumah tangganya. Berdasarkan hal tersebut dapat dilihat bahwa pendapatan daerah tidak dapat dipisahkan dengan belanja daerah, karena adanya saling terkait dan merupakan satu alokasi anggaran yang disusun dan dibuat untuk melancarkan roda pemerintahan daerah. (Rozali Abdullah, 2010). Sebagaimana halnya dengan negara, maka daerah dimana masing-rnasing pemerintah daerah mempunyai fungsi dan tanggung jawab untuk meningkatkan kehidupan dan kesejahteraan rakyat dengan jalan melaksanakan pembangunan disegala bidang sebagaimana yang tercantum 
dalam Undang-Undang Nomor 32 Tahun 2004 tentang Pemerintah Daerah bahwa "Pemerintah daerah berhak dan berwenang menjalankan otonomi, seluas-Iuasnya untuk mengatur dan mengurus sendiri urusan pemerintahan berdasarkan asas otonomi dan tugas pembantuan". (Pasal 10). Adapun sumber-sumber pendapatan asli daerah (PAD) sebagaimana datur dalam Undang-Undang Nomor 32 Tahun 2004 Pasal 157, yaitu:

1. Hasil pajak daerah;

Pajak merupakan sumber keuangan pokok bagi daerah-daerah disamping retribusi daerah. Pengertian pajak secara umum telah diajukan oleh para ahli, misalnya Rochmad Sumitro yang merumuskannya pajak lokal atau pajak daerah ialah pajak yang dipungut oleh daerah-daerah, seperti Provinsi, Kotapraja, Kabupaten, dan sebagainya, pajak negara yang diserahkan kepada daerah dan dinyatakan sebagai pajak daerah berdasarkan peraturan perundang-undangan yang dipergunakan guna membiayai pengeluaran daerah sebagai badan hukum publik. Dengan demikian ciri-ciri yang menyertai pajak daerah dapat diikhtisarkan seperti berikut:

a. Pajak daerah berasal dan pajak negara yang diserahkan kepada daerah sebagai pajak daerah

b. Penyerahan dilakukan berdasarkan undang-undang

c. Pajak daerah dipungut oleh daerah berdasarkan kekuatan undang-undang dan/atau peraturan hukum Lainnya;

d. Hasil pungutan pajak daerah dipergunakan untuk membiayai penyelenggaraan urusan-urusan rumah tangga daerah atau untuk membiayai perigeluaran daerah sebagai badan hukum publik;

2. Hasil retribusi daerah

Sumber pendapatan daerah yang penting lainnya adalah retribusi daerah.
Pengertian retribusi daerah dapat ditetusuri dan pendapat-pendapat para ahli, misalnya Panitia Nasrun merumuskan retribusi daerah adalah pungutan daerah sebagal pembayaran pemakalan atau karena memperoleh jasa pekerjaan, usaha atau mhlik daerah untuk kepentingan umum, atau karena jasa yang diberikan oleh daerah balk Iangsung maupun tidak Iangsung (Vita Amaliah, 2014).

Dari pendapat tersebut di atas dapat diikhtisarkan ciri-ciri pokok retribusi daerah, yakni:

a. Retribusi dipungut oleh daerah

b. Dalam pungutan retribusi terdapat prestasi yang diberikan daerah yang Iangsung dapat ditunjuk

c. Retribusi dikenakan kepada siapa saja yang memanfaatkan, atau mengenyam jasa yang disediakan daerah;

3. Hasil pengelolaan kekayaan daerah yang dipisahkan

Kekayaan daerah yang dipisahkan berarti kekayaan daerah yang dilepaskan dan penguasaan umum yang dipertanggung jawabkan melalui anggaran belanja daerah dan dimaksudkan untuk dikuasai dan dipertanggungjawabkan sendiri.

Sedangkan Prostitusi berasal dari bahasa latin pro-stituere atau prostauree yaitu membiarkan diri berbuat zinah, melakukan persundalan, percabulan, dan pergendakan. Sementara itu Bonger dalam Satyawan (2009) dalam tulisannya "Maatschapelijke Oorzaken der Prostitutie" mengatakan bahwa prostutusi adalah gejala kemasyarakatan dengan perempuan menjual diri melakukan perbuatanperbuatan seksual sebagai mata pencaharian.

Dalam perkembangan pariwisata, tidak bisa dipungkiri bahwa Prostitusi terkadang menjadi salah satu faktor pendorong perkembangan dunia pariwisata. Itu disebabkan adanya 
kebutuhan manusia akan rekreasi dan hiburan. Sementara itu, perwujudan dari tuntutan itu diwujudkan dalam bentuk hotel, diskotik, cafe, pub, panti pijat, tempat wisata dan sebagainya. Dalam kebutuhan rekreasi ini tidak terbatas pada musik, makanan, minuman dan cinderamata, tetapi juga memenuhi kebutuhan seksual. Dalam konteks inilah dunia pariwisata secara langsung maupun tidak langsung mendukung berkembangnya prostitusi untuk memenuhi kebutuhan. Perkembangan prostitusi dalam dunia pariwisata ini juga didorong oleh kebijakan pembangunan yang tidak merata di semua wilayah suatu negara. Perkembangan ekonomi yang pesat di kota-kota menjadi daya tarik penduduk pedesaan untuk berimigrasi, sehingga tidak mengherankan bila sebagian besar PSK diperkotaan dan daerah tujuan wisata berasal dari pedesaan.

Menurut Kartini Kartono (2011) Hal ini terjadi karena tidak semua perempuan berhasil mendapat pekerjaan layak di perkotaan dan daerah wisata, hal itu juga diperparah karena banyak perempuan-perempuan tersebut berpendidikan rendah dan tidak memiliki ketrampilan yang disyaratkan. Akhirnya sebahagian dari mereka masuk dunia prostitusi melalui jaringan tertentu untuk ditempatkan di sejumlah hotel, panti pijat, diskotik yang sebagain besar merupakan tempat pendukung pariwisata. Hal ini harus dimanfaatkaan oleh Pemerintah Daerah dan tugas dari Dinas Pendapatan Asli Daerah untuk dapat menagih retribusi dari pengelola tempat-tempat prostitusi agar keuntungaan tidak hanya diperoleh oleh swasta tetapi daerah juga mendapatkan keuntungan yang masuk ke kas daerah dimana pendapatan asli daerah tersebut berguna untuk pembangunan dan kesejahteraan masyarakat di daerah. Hal tersebut tidak melanggar undang-undang hanya saja agama, adat istiadat, moral dan etika yang sedikit menjadi penghalang dari terlaksananya melegalkan lokalisasi prostitusi di daerah.

Dalam hal ini emerintah harus tegas, tidak boleh hanya mengikuti kebiasaan dan keinginan orang banyak yang sedikit munafik. Di satu sisi masyarakat menolak adanya prostitusi tetapi di sisi yang lain banyak masyarakat tersebut merupakan pelaku dari kegiatan saling membutuhkan tersebut. Melegalkan prostitusi dan melokalisasikannya adalah solusi yang baik agar penyakit kelamin tidak menyebar kemana-mana, dan keuntungan yang lain pemerintah mendapatkan pemasukan bagi kas daerah.

\section{METODE PENELITAN II.1. Teknik Pengumpulan Data}

Dalam meneliti permasalahan ini, peneliti menggunakan metode kualitatif. Metode kualitatif sebagai prosedur penelitian yang menghasilkan data deskriptif berupa kata-kata tertulis maupun lisan dari orang-orang yang yang diamati. Metode ini memakai cara atau teknik penelitian yang membuat deskripsi sejelas mungkin mengenai objek yang akan diteliti dan akan menerangkan secara fakta karakteristik populasi yang ada dilapangan. Penelitian deskriptif dapat diartikan sebagai prosedur pemecahan masalah yang akan diselidiki dengan menggambarkan atau melukiskan keadaan subjek dan objek penelitian pada saat sekarang berdasarkan fakta-fakta atau sebagaimana adanya, Meleong (2009). Metode deskriptif adalah pencarian fakta dengan interprestasi yang tepat.

Penelitian deskriptif mempelajari masalah-masalah dalam masyarakat serta tata cara yang berlaku dalam masyarakat serta situasi-situasi tertentu, termasuk tentang hubungan kegiatankegiatan, sikapsikap, pandanganpandangan serta proses-proses yang berlangsung dan pengaruh-pengaruh dari 
suatu fenomena. Subjek penelitian atau responden adalah pihak-pihak yang dijadikan sebagai sampel dalam sebuah penelitian. Subjek penelitian juga membahas karakteristik subjek yang digunakan dalam penelitian, termasuk penjelasan mengenai populasi, sampel dan teknik sampling (acak/non-acak) yang digunakan. Maka dari itu Responden/sampel dalam penelitian ini yaitu:
A. WTS: Wanita Tuna Susila
B. Germo/Mucikari.

\section{II.2. Alat Pengumpul Data}

\section{A. Observasi}

Observasi adalah cara melihat atau mengamati suatu kejadian dari luar sampai kedalam dan kemudian melukiskan secara tepat seperti apa yang dilihat dan diamati. Observasi tid akterbatas kepada penglihatan (visual) saja, tetapi pengalaman yang diperoleh dari pendengaran. Observasi dilakukan untuk melihat latar belakang sosial budaya dari para PSK dan respon masyarakat terhadap lokalisasi prostitusi yang ada di Bukit Lawang. Pengamatan yang dilakukan adalah pengamatan partisipasi. Pengamatan partisipasi dengan teknik "part time participant observer" dipilih agar peneliti dapat terlibat secara langsung dilapangan tanpa harus menetap tinggal dilapangan. Dengan demikian data dapat diperoleh secara objektif dan terencana.

\section{B. Wawancara}

Salah satu upaya yang dilakukan untuk memperoleh data yang akurat adalah dengan mengadakan wawancara langsung kepada responden. Wawancara dilakukan untuk mengetahui lebih akurat mengenai prostitusi yang ada di Bukit Lawang dan bagaimana respon masyarakat terhadap kegiatan prostitusi yang ada di Bukit Lawang tersebut. Wawancara terbuka yaitu jawaban dan keterangan dari para responden tidak hanya mengucapkan keteranganketerangan atau cerita yang panjang dimana responden boleh menjawab secara bebas menurut isi hati atau pikirannya. Dengan demikian peneliti memperoleh gambaran yang luas tentang masalah itu. Didalam penelitian ini informan sangatlah dibutuhkan agar tercapainya kesempurnaan penelitian. Yang menjadi informan dari penelitian ini yaitu para PSK, germo atau mucikari, dan masyarakat yang ada disekitar Desa Bandar Baru.

\section{TEKNIK ANALISIS DATA}

Teknik analisis data yang digunakan adalah teknik analisis kualitatif. Digunakan pendekatan kualitatif ini dengan pertimbangan yaitu: 1. Teknik analisis kualitatif lebih mudah apabila berhadapan dengan realita ganda.

2. Teknik analisis kualitatif ini menyajikan secara langsung hakekat hubungan antara peneliti dengan responden.

Selanjutnya, analisa data yang sudah terkumpul dari catatan dilapangan dengan melakukan aktivitas antara lain:

1. Mengelompokkan data sesuai dengan jenis dan karakteristiknya yang dariberbagai sumber dilapangan. Hal ini diperlukan agar mempermudah penelitian dalam membedakan data pokok dan data penunjang.

2. Melakukan kategori data yaitu pengkategorian, Meleong (2009) yang menguraikan kategori sebagai berikut:
a. Pengelompokan kartu kedalam bagian isi yang secara jelas berkaitan.
b. Penetapan inklusi setiap kategori yang dapat digunakan untuk menetapkan keabsahan data.
c. Mengharuskan setiap kategori dilaksanakan taat asas, artinya lapping dalam penerapannya. tidak direkayasa dan over

3. Melakukan interprestasi data yaitu sesuai dengan tujuan prosedural, penerapan dan pelaksanaan 
penelitian sehingga mampu memberikan jawaban atas masalah penelitian.

\section{PEMBAHASAN}

\section{V.1. Transaksi Tawar Menawar}

Bagi PSK yang memiliki germo, sepertiga menjadi bagian germo, dari waktu ke waktu PSK memiliki tarif yang tidak tertulis. Tergantung dari kesepakatan PSK dengan tamunya. Untuk kencan singkat atau short time biasanya paling rendah Rp.300.000,- dan biaya penginapan atau kamar dikenakan biaya Rp.200.000,- untuk satu malam. Untuk kencan semalam atau long time biasanya paling rendah Rp. 500.000,-. Tarif ini berlaku pada saat penelitian ini dilaksanakan yaitu pada tahun 2019. Tarif untuk PSK tersebut tidak resmi namun merata, masyarakat di sekitar tempat penelitian pun mengetahui tarif ini. PSK biasa meminta bayaran yang lebih atau tamunya yang berkenan memberi tips yang lebih. Tamu akan jarang menawar apabila di hari sabtu, minggu dan di bulan muda dan apabila malam telah larut atau cafe-cafe sedang sepi terkadang harga bisa dinegosiasikan agar tamu mendapatkan harga yang lebih murah dari yang biasanya. Pembicaraan soal tarif jarang dibicarakan di dalam cafe karena didalam cafe musik terlalu berisik dan tamu maupun PSK merasa kurang nyaman apabila membicarakan tarif didepan umum. Biasanya bila tamu tertarik ia akan mengajak PSK tersebut minum dan berjoget atau PSK tersebut akan meminta untuk dibelikan rokok pada tamu yang mengajaknya. Selama penelitian ini dilakukan, peneliti tidak pernah bertemu dengan PSK yang tidak merokok. Mereka sangat suka sekali merokok dan minum minuman keras. Setelah berjoget biasanya tamu dan PSK keluar cafe dan membicarakan mengenai harga. Kalau tidak cocok tamu akan mencari PSK yang lain. Tetapi itu jarang terjadi. Tamu langsung setuju selama harga yang diminta oleh PSK masih berkisar pada harga pasaran.

Sebahagian besar germo menuntut sepertiga bagian dari pembayaran tamu, namun bagi sebahagian germo yang mengasuh PSK dengan memberi makan, air dan listrik gratis menuntut setengah dari dari pembayaran tamu. Germo tidak menuntut tips yang diperoleh anak asuhnya tapi untuk bayaran pelayanan seks wajib disetor kepada germo. Transaksi kadang-kadang lancar sesuai tarif, adakalanya tawar menawar terjadi saat terjepit situasi. Dihari-hari biasa yang sepi tamu, sering terjadi ketidak sepakatan tawar menawar antara tamu dan PSK. Tamu sering menawar jauh lebih rendah dari harga pasaran, awalnya PSK bersikeras untuk mematok harga pasaran dan terjadilah perdebatan. Bila tamu sepi, akhirnya keinginan sang tamulah yang menjadi keputusan akhir dari kesepakatan.

Disalah satu cafe ada yang memakai makelar atau calo, para PSK dengan santainya duduk di kursi sambil kaki dilipatkan dan juga tampak PSK dengan wajah-wajah baru yang polos duduk dibangku-bangku cafe dengan dandanan seronok menggoda sambil berdandan. Terjadilah tawar menawar harga antara pelanggan dan makelar. Dalam kurun semalam, cafe tersebut bisa meraup untung banyak. Karena biasanya seorang PSK dalam satu malam bisa mendapatkan tamu alias pria hidung belang sekitar 2 s/d 3 tamu. Keuntungan tersebut diperoleh dari tips yang diberikan oleh PSK dan para pelanggan yang berbelanja di cafe tersebut.

\section{V.2. Kebijakan Pemerintah Daerah}

Dengan besarnya transaksi keuangan yang terjadi di lokalisasi prostitusi tersebut ternyata tidak ada sedikit pun retribusi yang diberikan pelaku prostitusi untuk kas daerah yang dikelola oleh Dinas Pendapatan Daerah 
Deli Serdang. Maka kebijakan untuk melegalkan lokalisasi prostitusi adalah suatu keharusan bagi pemerintah daerah yang pelaksanaannya bisa di atur dalam peraturan daerah (PERDA).

\section{SIMPULAN DAN SARAN VI.1. Simpulan}

Latar belakang seorang wanita melakukan pekerjaan sebagai PSK di karenakan alasan ekonomi. Kemiskinan dan kebutuhan hidup yang tinggi mengakibatkan mereka harus menjalani kehidupan sebagai PSK. Pekerjaan disektor formal tidak memberikan kesempatan kepada mereka karena mereka tidak memiliki kecerdasan yang cukup dan pendidikan mereka pun rendah. Latar belakang keluarga atau orang tua yang kurang memberikan perhatian dan kasih sayang, disia-siakan oleh kekasih maupun suami juga merupakan salah satu pemicu seorang wanita menjadi seorang PSK.

Sistem perekrutan PSK menggunakan jasa agen atau calo, dan germo juga terlibat, ini berarti ada sistem yang mengatur terlaksananya prostitusi secara profesional, untuk itu pemerintah daerah juga harus terlibat agar retribusi para pelaku prostitusi tersebut bisa secara konsisten disetorkan ke kas daerah.

Keberadaan para pelaku prostitusi tersebut berpengaruh terhadap roda ekonomi masyarakat disekitarnya maka pemerintah bisa memanfaatkan situasi tersebut untuk ikut andil mendapatkan keuntungan yang merupakan salah satu sumber pemasukan yang besar bagi kas daerah.

\section{VI.2. Saran}

Walaupun lokalisasi prostitusi memberikan dampak positif bagi perekonomian masyarakat bandar Baru, namun praktek prostitusi ini pada dasarnya bertentangan dengan normanorma kehidupan terutama pada norma kesusilaan dan norma agama. Dalam hal ini ada beberapa hal yang dapat dijadikan sebagai sarana untuk mengurangi dampak negatif dari praktek prostitusi tersebut. Kerjasama dan komunikasi antar masyarakat, Dinas Pendapatan daerah, perangkat desa dan aparat menjadi penentu terjalinnya kerjasama yang baik demi bertambahnya PAD untuk pembangunan di daerah.

\section{DAFTAR PUSTAKA}

Azwar, S., 2012, Metode Penelitian, Yogyakarta: Pustaka Pelajar

Hakim,Vita Amaliah, 2014. Analisis Efektivitas Pajak Daerah dan Retribusi Daerah Terhadap Pendapatan Asli Daerah (PAD) Kota Tasikmalaya (Studi Kasus Pada Dinas Pendapatan Kota Tasikmalaya). Tasikmalaya.

Kartono, K., 2011, Patologi Sosial, Jakarta: Raja Grafindo Persada.

Meleong, Lexy.J .2009, Metode Penelitian Kualitatif. Bandung : PT. Remaja Rosdakarya.

Pulungan, anwar. 2014, Analisis FaktorFaktor Yang Mempengaruhi Pajak Daerah.

Skripsi Fakultas Ekonomi, Universitas Sumatera Utara.

Prastya RK., C., dan Darma, A., 2011, Dolly: Kisah Pilu yang Terlewatkan, Yogyakarta:

\section{Pustaka Pena.}

Satyawan, H., 2009, Persepsi Stakeholder Terhadap Lokalisasi Villa Garden di

Kabupaten Karimun, Tesis: Universitas Gadjah Mada.

Silalahi, U., 2010, Metode Penelitian Sosial, Bandung: Refika Aditama.

Sugiyono, 2012, Metode Penelitian Kuantitatif Kualitatif dan $R \& D$, Bandung: Alfabeta

Suhadak \& Trilaksono, 2012, Pendapatan Asli daerah, Gramedia. 
Suyanto, B., 2012, Anak Perempuan Yang Dilacurkan: Korban Eksploitasi di Industri

Seksual Komersial, Yogyakarta: Graha Ilmu.

Syam, N., 2011, Agama Pelacur: Dramaturgi Transendental, Yogyakarta: LKiS.

UU No. 12 Tahun 2007 tentang Otonomi Daerah.
UU No. 28 Tahun 2009 tentang Pajak Daerah dan Retribusi Daerah.

UU No. 33 Tahun 2004 tentang Perimbangan Keuangan Antara Pemerintah Pusat dan

Pemerintah

Daerah. 